\title{
Reading the Bible Together with Muslims: David as Sinner King and Repentant Prophet
}

\author{
Karel A. Steenbrinkt \\ Emeritus Professor of Intercultural Theology, Utrecht University, \\ Utrecht, The Netherlands
}

Throughout his academic career Karel Steenbrink (1942-2021) studied Islam, especially in its Indonesian expressions. Yet Islam was not merely a research object for Steenbrink. He had numerous Muslim friends and - when permitted - willingly participated in Muslim rituals. This combination of in-depth knowledge of Muslim beliefs and practices and personal engagement with Muslims, led Steenbrink to theorize the relationship between Judaism, Christianity, and Islam as a hermeneutical family, drawing on a joint corpus of stories.

In the article below, first published in Exchange in 2006, Steenbrink makes this argument by means of a case-study of the stories about David in the three traditions. In republishing this article, we would like to commemorate Steenbrink who enthusiastically and competently served as managing editor of Exchange from 1994-2004 and celebrate his scholarship.

The editors

\begin{abstract}
The Jewish, Christian and Muslim traditions share many stories. The narratives about Adam, Abraham, Moses, Solomon and many others are modelled one after the other. During the last decades much attention has been given to the 'three religions of Abraham' as sharing the heritage of that great biblical figure. This contribution concentrates on the stories of David in the three religions as expression of the one hermeneutic family. It pleads that Jews and Christians take the Muslim reinterpretation of their heritage serious.
\end{abstract}

\section{Keywords}

Bible - Qur'an - hermeneutical family - intercultural theology - Christian-Muslim relations - comparative religion 
The readers of the Bible are sometimes described as a 'hermeneutic community' This means: An assembly of people who come together to read the Scriptures anew and who discover fresh wisdom and unsuspected applications. People do it not in isolation, but in the community of the global Church. What Christians consider as the Old Testament section of their Scripture, is in fact the specific heritage of the Jewish religious tradition. But still Christians feel entitled to read the Jewish scripture in a new way, to use it in church services. Not only the promise of God to the Jews but also the common use of Scripture is the basis of the special relation between Christians and Jews.

With Muslims this relation is somewhat different but certainly comparable. Muslims accept the scripture of Jews and Christians as revelation from God. In fact, several passages of the Qur'an are difficult to understand without familiarity with Jewish and Christian scripture. These passages sound like an elaboration, a practical application of themes from the Bible. Many passages of the Qur'an sound as a sermon directed to people who already know the basic story and now receive a new application for daily life. Muslims drink from the same source as Jews and Christians: from the same revealing God, who continued his work among mankind; from the same oral and literary revelation. Could we therefore also consider Muslims as part of the 'hermeneutic community', reading the stories from Adam, to Noah, Abraham, Moses, David and Jesus together with Jews and Christians? Are also Muslims members of the hermeneutic family, gathered around old and new interpretations of biblical texts and themes? This contribution wants to defend this thesis. It will also give one example, the story of David in Old Testament, New Testament and Qur'an. We will focus on the story of David and Bathsheba, up to the parable of Nathan, the prophet, who rebuked David for taking the wife of Uriah and killing this man.

\section{The Story of 2 Samuel 11-12}

After the story of Moses, the dramatic narrative of David's life is the longest and most spectacular saga in the Old Testament. It reads nearly like a soap opera: so many different characters featuring in this story, so many surprising moments and even sometimes a cliff-hanger! It starts in 1 Sam. 16 with the lively story of Samuel looking for the new candidate for king and the showing of the sons of Jesse. Only the youngest, David, not yet taken seriously by his father and brothers, is then elected. David fights Goliath, and gets into close relation to King Saul and his son Jonathan. The relation with Saul deteriorates very quickly, but Jonathan continues to be close to David. After his separation from Saul, David turns into a guerrilla-fighter, or a warlord on his own. As with 
many revolutionary people, David keeps his hands clean in the beginning: Saul's life is spared and the many people working for the rich capitalist farmer Nabal are saved. The story then sounds more like the tactics of Mafiosi seeking broad support with the poor. David sets his price for 'protection'. Nabal, the rich farmer near Mount Carmel, rejects a deal with David, but his wife Abigail sends a rich remuneration to David and his 400 men. Immediately after that Nabal dies and the widow Abigail is taken by David as his wife. Some scholars see a parallel with the story of Bathsheba who is made a widow by David and then also taken as his wife.

At this moment we may ourselves some questions: The prophet David of the Psalms is obviously different from the politician of 1 and 2 Samuel. In how far was David using methods of guerrilla fighters, resembling the tactics of the big Mafia bosses? Are just or clean wars possible? David is fighting both an external war (against Ammonites, Philistines, and other peoples of the region) and an internal fight against Saul and his party. Are 'holy land, holy kings' just part of that history of man and God: blessing mixed with sin? Some exegetical literature gives a rather active role to Abigail: was she conspiring to see her brutal man dead in order to marry David? Is this suggestion justified in the text of 1 Samuel 25 or should we rather seek it in the mind of the reader?

In a life full of changes and ruptures, one of the most dramatic events was the affair of David with Bathsheba, resulting in the early return of Uriah to Jerusalem, to have a conversation with David who suggested that he go home and 'wash his feet' (i.e. have intercourse with his wife in order to conceal the adultery of David?). Uriah rejects this (because of the sexual taboo related to holy warfare? Because he knew the sin of David and did not like to co-operate?) and is sent back to the battle, carrying with him the letter that is his death sentence. Nathan rebukes David with the parable of the rich man who steals the only ewe of his poor neighbour, whereupon David repents. The first child of Bathsheba with David dies, as also Amnon, Absalom and Adonijah. Solomon will be the successor to David, but there is a bloody stain on the reign of David. He will not build a temple, will not ride on horses, and 'the sword will never depart from your house' (2 Sam 12:10).

Within the Jewish scripture there is already a remarkable rewriting of the story of David. It is found in 1 and 2 Chronicles, compared to 1 and 2 Samuel and the Books of Kings as the more spiritual book, like the philosophical Gospel of John in relation to the more realistic synoptic gospels. 1 and 2 Chronicles focus on David as the superb glorious king and on the temple as the place of worship. They were probably written by Ezra, related to the re-establishment of the Israelites after the Babylonian captivity. David is here the ideal king. Therefore, his personal sin of adultery with Bathsheba and the killing of Uriah have been 
removed from the narrative of the books of Chronicles. It is another sin that is recalled in 1 Chronicles 21, the numbering of the people of Israel. This is seen here as an act of distrust in God or of pride about himself and his people. In this case the building of an altar and a great sacrifice is enough: according the mind of the author of Chronicles, a specialist in liturgies.

The Bible is taken as scripture, divine revelation, but at the same time it is a very human document, that also can arouse questions: Is David's story only a reminder of the general rule that power involves corruption? Is not only poverty, but also its generator and companion, violence and corruption, a timeless aspect of human society? Do we see similarities between David and the careers of a number of modern rulers who started as noble and good activists, but deteriorated, corrupted by power (think of Suharto of Indonesia, Mobutu of Congo)? Why is Abigail so active and full of initiatives, while Bathsheba is so silent and passive, as if she has no design for her own? (We have to recall that some blame her for not being discrete enough for bathing outside the house! Shame to false interpreters who only want to criticize women!).

The 'historical David' is not mentioned frequently in the New Testament. These references, however, several times mention an unorthodox, somewhat recalcitrant figure, who like Jesus himself also protested against fixed rules of the Jewish religion. In Mt 12:3-4 Jesus defends his deviation from a too strict observation of Sabbath rules with the example of David: 'when he and his companions were hungry. He entered He entered the house of God, and he and his companions ate the consecrated bread.' (see also Mk 2:25 and Lk 6:3)

Most references to David in the New Testament are to one of the 'son' variants, that all have a messianic connotation. Besides Son of God, Son of Man, we find the title of Son of David for Jesus. This must be understood in the contemporary hope of a return of three major Jewish figures: Moses, Elijah and (the kingdom of) David. This is theologically formulated in Rom 1:3-4 '... regarding his [= God's] Son, who as to his human nature was a descendant of David, and who through the Spirit of holiness was declared with power to be the Son of God by his resurrection from the dead: Jesus Christ our Lord.'

In the genealogy of Jesus in the first chapter of Matthew we find various references to dubious or even sinful persons and facts. Do we find also such an articulate reference to sin in Mt 1:6 about 'David who was the father of Solomon, whose mother had been Uriah's Wife'? 
Do we find here an antagonism, where the very human (and even sinful) origin from David is contrasted with the divine nature of Jesus as Son of God? There is a 'high' and 'low' Christology. Can we in this same sense also distinguish between a 'high' and a 'low' description for David? In some texts his earthly kingdom appears as the model for kingdom of God, while in other texts the very human sinner David is presented.

David's sin and repentance in the Qur'an and some other Islamic Literary Traditions

David is not among the most-discussed prophets of the Qur'an. He is credited with a holy book, the Zabür or Psalms, and as such he is among the small group of four predecessors of Muhammed who are connected with some kind of scripture (Abraham, Moses, David and Jesus). In this sense he is a member of the elite of the prophets. But there are many more verses dedicated to Moses (no 1), Abraham (no 2), Noah (no 3) and also to Jesus (no 4) and Adam (ranking 5) in the Qur'an than to David and Salomon who can be considered as ranking 6 and 7 in the priority scale of the pre-islamic prophets in the basic book of Islam. There is only one longer section on him in chapter or sura 38 . Besides, there are eight short references to the great prophet-king of the Jews. They should all be taken as references to stories already known to the audience, because they jump in just with a short section of the story and then offer a pious conclusion. Like a preacher who on a Sunday morning will not retell the story of the Good Samaritan, but only will make a short reference to the priest who 'passed by on the other side of the road' (by the way: not a bad image of the way many Christians treat the Qur'anic texts!).

Qur'an 2:246-251 is the first section on David. In fact it starts with the story of an unnamed prophet, definitely Samuel, who is asked to appoint a king for the Jews. As in 2 Samuel he is quite hesitant to follow this suggestion: 'Is it not possible, if you were commanded to fight, that you will not fight?' Thereupon Tālūt or Saul is appointed as their king. Curiously, Jālūt enters the story. The man with this curious name, similar to that of Saul, is Goliath, but apparently in the Qur'anic tale the twin Tālūt and Jālūt have become a couple, joining in evil. In 2:251 David enters the scene in full armour: 'David slew Goliath; and God gave him power and wisdom, and taught him whatever He willed. And did not God check one set of people by means of another, the earth would indeed be full of mischief. But God is full of bounty to the whole world. This is a pious meditation about a story already known, not the story itself, which must have been known to the first audience of the Qur'an. 
In 4:163 David is only among a long list of some 12 important prophets (also in 6:84). 5:78 is the conclusion of a long section condemning the Christians for making Jesus the Son of God and a member of the Trinity: 'Cursed were the unbelievers of the children of Israel by the tongue of David and Jesus, Mary's son; that, for their rebelling and their transgression. The Qur'an has several verses that emphasize the equality of the prophets. A major example is 2:136, stating that the believers 'make no difference between one and another of them'. Some readers even complain therefore that the Qur'anic image of the prophets is rather flat, because they seem all modelled after one major example. But still, this is a lovely contradiction in God's word! There are also verses that do make the difference between the prophets. As one of the proofs of God's benevolence, there is in 17:55 a short reference to David: 'We did bestow on some prophets more and other gifts than on other: and We gave to David the Psalms.'

21:78-80 has some puzzling references to biblical stories or Jewish legend. Verse 78 mentions David and Solomon 'when they gave judgment in the matter of the field into which the sheep of certain people had strayed by night.' Is this a rather obscure reference to the story of the rich owner of many sheep who stole the one sheep of the poor, as told by Nathan to David? Verse 80 has a reference to God who taught David 'the making of coats of mail for your benefit, to guard you from each other's violence.' This is not based of biblical material but on Haggadic stories. ${ }^{1}$ This is also a proof of the fact that the Qur'an did correspond to the living Jewish tradition rather than to written scripture alone.

Qur'an 27,15 has a reference to David and Solomon together: 'We gave knowledge to David and Solomon. And they both said: Praise be to God who has favoured us above many of his servants who believe.' In 34:10 there is another reference to David as singer of Psalms: 'We gave David bounty from Us. O ye mountains, sing you back the praises of God with him! And you birds! And we made the iron soft for him.' In verse 34:11 it is further explained that David had the gift of making coats of mail, balancing well the chains of armour. This apparently emphasises the king, warrior and ruler, rather than the singer of Psalms who is seldom mentioned in the Qur'an.

\subsection{The Major Qur'anic Account of David: the Repentant King in Disguise} Besides the short and dispersed occurrences of David as a religious hero of the past, there is a striking version of the Nathan-story in the 38th chapter (or: süra) of the Qur'an. This section (38:17-28) may be divided in three parts.

1 Heinrich Speyer, Die biblischen Erzählungen im Qoran, Hildesheim: Ohms 1961 (reprint of the first edition of 1931), 382 . 
The first is basically a description of the easy and quick glory of David, but the word penitence already creeps in as the most important characteristic for the Qur'anic David: 'Remember our servant David, the man of might; he was a penitent. With him We subjected the mountains to give glory at evening and sunrise, and the birds, duly mustered, every one to him reverting. We strengthened his kingdom, and gave wisdom and speech decisive.' (38:17-20)

After this short introduction we read the story of Nathan, but in its typical Qur'anic style of a short theatre play with the actors directly pleading to king David. We see a rich man, owner of many cattle, and his opponent, the poor man whose only ewe lamb was taken by the greedy rich man. These two address David in the sanctuary, probably to be seen as the temple of Jerusalem, or at least a sacred place.

Has the tiding of the dispute come to thee? When they scaled the Sanctuary, when they entered upon David, and he took fright at them; and they said: 'Fear not, two disputants we are. One of us injured the other. So judge between us justly, and transgress not, and guide us to the right path.' 'Behold this my brother has ninety-nine ewes, and I have only one ewe. So he said: "Give her into my charge" and he overcame me in the argument.' Said he [=David] 'Assuredly he has wronged thee in asking for thy ewe in addition to his sheep; and indeed many intermixers do injury against the other, save those who believe, and do deeds of righteousness. And how few they are!' And David thought that we had only tried him. Therefore he sought forgiveness of his Lord, and he fell down, bowing, and he repented. Accordingly, We forgave him that, and he has a near place in Our presence and a fair resort. (38:21-25)

The section ends with a conclusion, where David is warned that his great power should not be used in the style of so many rulers before and after him, who abuse their position: 'David, behold, We have appointed thee a viceroy in the earth; therefore judge between men justly, and follow not caprice, lest it lead thee astray from the way of God. Surely those who go astray from the way of God, there awaits them a terrible chastisement, for that they have forgotten the Day of Reckoning.' (38:26)

We should add a few notes on this text from the Islamic commentaries: until the third century of Islam, there was comfortable use of the biblical narrative for the interpretation of this text. The famous Abu Ja'far ibn Jarir At-Tabari $\left(853^{-923}\right)$ considered this text as a short version of the text of 2 Sam 12. Later Muslim interpreters had problems with the fact that a great king and prophet should have committed the grave sin of adultery. Therefore the word of the first 
verse 'penitent' is by some translated as 'pious'. The 'mountains giving glory' of the first section are seen as part of the psalms, where the whole nature is summoned to give glory and praise to the Lord. About the birds it is said, that they joined David in praising the Lord, when they heard him singing the Psalms.

The central text of the two men who 'scaled the sanctuary' is seen as an irruption on David, who was saying his favourite prayer of istighfar, or asking forgiveness. It is added in modern commentaries, that it is very good for all people and at all times to ask for forgiveness, even if we make only minor mistakes. With the common exaggeration of pious commentators it is quoted from old commentaries, that David was more or less a champion in the practice of asking for forgiveness. He is seen as one who spent one third of the night for this special prayers for forgiveness and had fasted about half of the days of his life. The reaction to the unexpected arrival of the two men disturbing him while he was praying in the sanctuary is explained because one should never disturb someone else who is praying. Moreover, this prayer of forgiveness is said during the night and it is not allowed to come to the house of people after the last prayer of the day ('isha') and before the first prayer of the morning. ${ }^{2}$

The central story about the man with the 99 sheep and the one with only one ewe is nowadays seldomly referred to the person of David himself. Most commentators refer to the story of 2 Samuel 12, but hesitate to apply it to David out of respect for this important king and prophet. They also see no convincing reason to accept in full the biblical narrative. The well-known Pakistani translator and commentator of the Qur'an, A. Yusuf Ali wrote on this episode: 'Judged by ordinary standards, David had done no wrong: he was a good and just king, judged by the highest standard of those nearest to God. ${ }^{3}$

Not only the story of Jesus has caused debate between Muslims and Christians. Also the story of David may be the start of a debate on the modern interpretation of this episode. How seriously must we take that prophets were human beings? How could Christians take David as an example, from the New Testament text and onwards, while they consider him also as a sinner?

2 See on 38:21-25: Hamka (acronym of Haji Abdulmalik ibn Abdulkarim Amrullah), Tafsir alAzhar, Jakarta: Nurul Islam 1967, 3 o vols. Many reprints; Shihab, M. Quraish, Tafsir al-Misbāh, Jakarta: Lentera Hati 2000, 15 vols.

3 Abdullah Yusuf Ali, The Holy Qur'an. Text, Translation and Commentary, Lahore: Muhammad Ashraf 1938 (many reprints). 


\subsection{The Contested Combination of Prophet and Ruler, Religion and Politics}

Since the revelation of the Qur'an the Islamic community has produced a large quantity of religious texts. Many of these must be seen as commentaries, additions and even corrective adaptations of the basic text to the need of various people and varying times. For our purpose, the genre of the Tales of the Prophets is an important literary corpus. It started out of the popular commentaries on the stories of the Jewish and Christian key-figures, from Adam to Noah, Abraham, Moses, David and Solomon, Mary and Jesus. Different from the very strict interpretation of the more juridical texts of the Qur'an and the additional traditions (hadith) related to the prophet Muhammad and his companions, there is a rather free narrative style in the Tales of the Prophets. The honest and strict defender of orthodoxy in Baghdad, Abdurrahman ibn al-Jauzi (1126-1200) wrote a book about or rather against popular preachers and storytellers (qussās). ${ }^{4}$ To the judgment of this cataloguer of heresies, this group mixed their pious stories too much with jokes and even spicy anecdotes in order to get a larger audience and earn more money. But also this reformer had to acknowledge that the pious Caliph Umar appointed Tamim al-Dari with the sole purpose to edify the common people. Some scholars complained that there were only few students in the classes of the learned in the mosque, while huge crowds attended the light speeches of the pious entertainers in front of the mosque. ${ }^{5}$

For our purpose it is quite interesting to note that the genre of the Tales of the Prophets (Arab: Qisāsul anbiya) has included not only free adaptations of the stories, but also new material from converted Jewish rabbis or learned Christians, or even directly from the Jewish and Christian scripture. As such they represent another link in what are called 'Intertwined Worlds', the ongoing interaction between Judaism, Christianity and Islam. ${ }^{6}$ This is already clear in the start of the David story in the major tradition which we will use, that of the Turkish author Muhammad bin Khāvendshāh bin Mahmūd, commonly called Mirkhond (1433-1498, writing in Persian). In the opening section of his story on David he mentions that David was of the tribe of Juda and a son of Aisha (=Jesse). In contrast to the isolated fragments of the Qur'anic account, we have in Mirkhond a running story written in a very lively style. This account

4 Ignaz Goldziher, Muhammedanische Studien, Halle: Niemeyer 189o, volume 2, 161-171.

5 Karel A. Steenbrink, Adam Redivivus. Muslim elaborations of the Adam Saga, Zoetermeer: Meinema 1998, 105-124; 'Jesus as a Javanese Prophet', in: Martha Frederiks et al. (eds.), Towards an Intercultural Theology. Essays in honour of Jan A.B. Jongeneel, Zoetermeer: Meinema 2003.

6 Hava Lazarus-Yafeh, Intertwined Worlds. Medieval Islam and Bible Criticism, Princeton: Princeton University Press 1992. 
of 1 Samuel 16 about the election of David to become king is somewhat exaggerating the biblical story. Samuel finds none of the sons of Jesse as the one chosen by God. And he asks Jesse about more sons. The bible relates that Jesse said: 'There is still the youngest, but he is tending the sheep.' In the story of the 15th century Persian historian Mirkhond it is much more dramatic:

The father replied: 'I have no other son'. Samuel continued: 'The Lord who knows what is patent and what is concealed, has informed me that thou hast another son'. Jesse said: 'I have a little son, but on account of his small stature, blue eyes, and want of beauty, I do not consider him to be a man. Now he is engaged in yonder place pasturing the sheep'. Samuel went to the locality, arrived in a valley abundantly provided with water, and there he perceived David, taking up two sheep at a time and crossing the water with them. Samuel now perceived by the light of prophecy that in this individual case the promise would be fulfilled. ${ }^{7}$

From this short passage it is already clear that this Islamic version has embellished and boosted the story that was not mentioned at all in the Qur'an. The same occurred in the elaboration of the Qur'anic story of the two men who came to David about the 99 and the one sheep. Mirkhond starts his story with a picture of David reading psalms and praying, but also boasting to God about his piety and even challenging the Allmighty: 'My God! Send me a trial that I may be patient under it, and that I may thereby become worthy of thy favours.' Thereupon a miraculous bird appeared: 'its beak was of red rubies, its eyes of emeralds, and its feet of turquoises.' David follows the bird because he wants to catch it and give it as a present to his youngest son. The bird leads to the roof of a house where a handsome woman was bathing. When Bathsheba noticed that someone arrived she scattered her hair in such a manner that it covered her whole stature. But still, David was captivated by the wish to have her as his spouse. He came to know that Uriah was her husband. David sent a letter to the army that Uriah should be posted in the front lines of the army. There he was killed. Mirkhond here gives two version of David's fault, a severe and a milder version. 'The sin of David consisted in harbouring in his mind the intention of marrying the wife of Uriah, in case he should fall in battle. According to another opinion his lordship's sin was that he asked Uriah to divorce his wife, which he, however, refused to do.' The story continues with the arrival of two men fighting about one ewe: the rich one who owned 99 and the poor who only had one

7 Mirkhond, The Rauzat-us-Safā or Garden of Purity, London: Royal Asiatic Society 1892, volume 1,47 . 
ewe. Thereupon David repented and was forgiven by God. But he did not feel this as sufficient. He went to the tomb of Uriah, who replied: 'Who is it disturbing my sleep?' Uriah did not answer further when David asked for forgiveness and confessed: 'I have sent thee to the war, to cause thee to drink the beverage of martyrdom, that I might take possession of thy wife.' David continued to lament his fate, but finally only heard the word of the Lord: 'O David, how can Uriah on the day of resurrection quarrel with thee, after I bestow upon him the blessings of paradise, hūris and palaces, when he will be pleased with thee, and will place the ledger of enmity upon the balcony of oblivion?' Notwithstanding this message, David was in a state of perpetual melancholy and repentance during the further thirty years of his life. (Mirkhond 1892:61-66)

The British scholar Edward Brown ${ }^{8}$ criticized the verbose style of Mirkhond: 'It was under Tartar, Turkish, Indian and other non-Iranian patronage that this inflated rhetoric especially flourished.' Whether we like this verbose elaboration or not, we have to recognise that it is a marvellous example of contextual reading of the common scripture of Jews, Christians and Muslims, in new words applying the basic message of the story. In this way the story presents the three religious traditions as one hermeneutic family, bravely criticising a prophet and king for his failure.

Another Islamic tradition here is the genre of mirrors for kings, books written to summarise the qualities of the ideal king. A major example in this genre is attributed to the great scholar Abu Hamid al-Ghazali (d. 1111). In this genre all major Jewish prophets are praised for their double quality of being a king and a prophet, combining the leadership of this world and guidance for the hereafter in one person. The series also starts with Adam, continuing with Noah and Abraham. Joseph is of course one of the major representatives of the double function of a king and a prophet, followed by Moses. David and Solomon are the summit but in most cases also the last examples of this combination. It is striking to see that most stories tell about pious, even ascetic and sober living kings. This starts with Adam who led a life of repentance, afraid that he would made a mistake again like the failure of paradise, and would be sent to hell from his earthly abode. Also David is in these stories depicted as a humble, hard-working, fasting and praying king. Sometimes he reminds us of the Buddhist stories of the royal prince who left the royal dignity and started a life as a hermit. Some of this is found in a Malay 'Mirror for Kings' the Tajus Salatin or Crown of the Sultans that was used at Malay courts from the 15th century. Here David is depicted as someone who asked from God a favour of learning

8 Edward G. Brown, A Literary History of Persia, 1956, volume 3: (1265-1502), Cambridge: Cambridge University Press 1956, 433 . 
a simple job, in order to earn a living for himself, in order not to be dependent from the taxes and gifts of his people. In reference to Qur'an 21:80 and 34:11, already summarised above, God taught him how to make coats of mail, for his own use and for other people who ordered them from him. ${ }^{9}$

In a popular distinction between Islam and Christianity it is often said that for Islam religion and politics are one, united, while they would be separated for Christians. Sometimes the example of the older prophets is recalled, in line with the double function of prophet and statesman for Muhammad ${ }^{10}$. From the concrete example of the classical writings quoted above, we may gather a quite different picture of the popular slogan, that in Islam religion and politics should be united.

In the framework of contextual reading of scripture, the Islamic examples, as given above, show that familiarity with a rich tradition of reading and interpreting scripture in the Islamic community may be very fruitful. It shows that Islam started as a somewhat recalcitrant, even obstinate member of the Jewish and Christian tradition, but also cherished some of its features. In the course of history more contacts resulted again in newer combinations between the communities and this history of intertwining can continue also in this 21st century. It may look like a rather soft approach to Islam, overlooking the differences between the two religions. But theologians of this era should not too easily join the political interest in its search for a new major enemy after the fall of communism. They should seek the best in the tradition of the other. That is the prophetic task of theology in this new era of confrontation. David is only one of the many prophets of the past who may help us in this task.

\section{About the Author}

Karel A. Steenbrink (1942-2021) was professor of Intercultural Theology at the Faculty of Theology of the Utrecht University and director of the Centrum IIMO. He was an expert in Indonesian Islam and Christianity and frequently published about biblical figures in the Islamic tradition. These publications include: 'Indonesian Interpretations of the Adam Legend', Nusantara:Journal for Southeast Asian Islamic Studies 2/2 (2000), 117-153; 'The Queen of Sheba in Jewish, Christian and Muslim Traditions: The Good News in Interscriptural Readings', in: Teresa Okure (ed.), To Cast Fire upon the Earth: Bible and Mission

9 Brannon W. Wheeler, Prophets in the Quran, London: Continuum 2002, 259-265.

10 Montgomery Watt, Muhammad, Prophet and Statesman, Oxford: Oxford University Press 1961. 
Collaborating in Today's Multicultural Global Context. Pietermaritzburg: Cluster 2000, 148-161; 'Jonah: From a Prophetic Mission in Reverse to Inter-religious Dialogue', International Review of Mission 36o, 91 (2002), 41-51; Jesus as a Javanese Prophet', in: Martha Frederiks et al. (eds.), Towards an Intercultural Theology. Essays in honour of Jan A.B. Jongeneel, Zoetermeer: Meinema 2003, 137-152; De Jezusverzen in de Koran/The Jesus verses in the Qur'an, Zoetermeer: Meinema 2006/Hyderabad: HMI 2011. 